\title{
Linkage Analysis of a Kindred with Inherited 46,XY Partial Gonadal Dysgenesis*
}

\author{
J. S. FUQUA, E. S. SHER, P. Y. FECHNER, H. OSTRER, C. ODDEUX, \\ A. J. SCHAFER, T. O. ROSALES, C. J. MIGEON, AND G. D. BERKOVITZ \\ Division of Pediatric Endocrinology, Johns Hopkins University School of Medicine (J.S.F., E.S.S., \\ P.Y.F., C.J.M., G.D.B.), Baltimore, Maryland 21287-3311; the Human Genetics Program, Department \\ of Pediatrics, New York University Medical Center (H.O., C.O.), New York City, New York 10016; the \\ Laboratory of Human Molecular Genetics, Human Genetics, University of Cambridge (A.J.S.), \\ Cambridge, United Kingdom; and the Newfoundland and Labrador Medical Genetics Program, \\ Charles A. Janeway Child Health Center and Memorial University of Newfoundland (T.O.R.), \\ St. John's, Newfoundland, Canada
}

\begin{abstract}
We have reported a kindred in which $46, \mathrm{XY}$ gonadal dysgenesis was inherited in an X-linked (or autosomal dominant sex-limited) manner and in which affected subjects did not have a large duplication of the short arm of the X-chromosome. In the present study we used linkage and sequence analyses to test the role of $\mathrm{X}$-linked and various autosomal genes in the etiology of the familial $46, \mathrm{XY}$ partial gonadal dysgenesis.

For analysis of X-linkage, 28 microsatellite polymorphisms and 1 restriction fragment length polymorphism were studied. The genotypes of informative family members were determined at each locus, and data were analyzed. Despite the large number of loci tested, our studies did not establish linkage between the trait and an X-chromosomal locus.
\end{abstract}

With respect to the study of autosomal genes, linkage analysis using a polymorphism within the 3 '-untranslated region of the WT1 gene excluded involvement of WT-1 in the etiology of the abnormal gonadal differentiation of the family in this study. Similarly, linkage analysis using four microsatellites on the distal short arm of chromosome 9 was not consistent with linkage. Linkage analysis of a locus close to the SOX9 gene as well as analysis of the coding region of the SOX9 gene suggested that this gene was not associated with the trait in the affected subjects we studied. Our data suggest the role of an autosomal gene in the abnormal gonadal differentiation in the family in the study, but do not formally exclude the role of an X-chromosome gene. (J Clin Endocrinol Metab 81: 4479-4483, 1996)
$\mathrm{T}$ HE STUDY of subjects with $46, \mathrm{XY}$ complete gonadal dysgenesis has helped to identify the sex-determining region $Y$ gene (SRY) that encodes the testis-determining factor $(1,2)$. However, mutations in the SRY gene account for a relatively small number of affected subjects (3-5).

Some evidence for the role of an X-linked gene in testis determination comes from the study of various kindreds in which $46, X Y$ complete gonadal dysgenesis was inherited as an X-linked or sex-limited autosomal dominant trait and in which there was no apparent duplication of the X-chromosome (6-9). Additional evidence comes from cases of 46,XY complete gonadal dysgenesis that have been associated with duplications of the short arm of the X-chromosome between Xp21.2 and Xp22.1 (10-14). Analysis of submicroscopic duplications identified a region termed the dosage-sensitive sex

Received November 14, 1996. Revision received August 2, 1996. Accepted August 6, 1996.

Address all correspondence and requests for reprints to: Gary D. Berkovitz, M.D., CMSC 3-110, 600 North Wolfe Street, Baltimore, Maryland 21287-3311.

* This work was supported in part by NIH Grants R01-HD-28318, R01-DK-00180, 1-K08-HD-01039-02, and P30-HD-27799-05; NIH Training Grant T32-DK-07116; and the Lawson Wilkins Genentech Clinical Scholar Award. This work was also supported by Wellcome Trust Grant 035201-2-92. This research was conducted while P.Y.F. was a Pfizer Scholar. This article was coauthored by LCDR Fuqua, M.C., U.S.N., while a fellow in Pediatric Endocrinology at Johns Hopkins University School of Medicine. The views expressed in this article are those of the authors and do not reflect the official policy or position of the Department of the Navy, Department of Defense, or the U.S. government. reversal (DSS) locus. This locus contains the adrenal hypoplasia congenita gene (15). The syndrome of X-linked $\alpha$-thalassemia/mental retardation has been associated with abnormal testis development and results from mutations in the $\mathrm{XH2}$ gene, located in Xq13.3 $(16,17)$.

Some cases of $46, X Y$ complete gonadal dysgenesis have been associated with mutations of the Wilms' tumor suppressor (WT1) gene (18) or with mutations of the SOX9 gene; the latter was recently identified as the gene involved in camptomelic dysplasia $(19,20)$. Deletions of the distal short arm of chromosome 9 have also been detected in cases of $46, X Y$ partial gonadal dysgenesis $(21,22)$.

In 1993, we reported a kindred in which $46, X Y$ partial gonadal dysgenesis was inherited as an X-linked (or autosomal dominant sex-limited) trait (23). Affected subjects had no other congenital anomalies. The kindred included four affected individuals in two generations. The sequence of the open reading frame of SRY was normal. In addition, Southern analysis was performed using six $X p$ specific loci to investigate a duplication of the short arm of the X-chromosome. This study was also negative and excluded a large duplication of the short arm of the X-chromosome. The absence of mental retardation and characteristic facial features excluded the $\alpha$-thalassemia/mental retardation syndrome. In the present study, we used linkage analysis and sequence analysis to test the possible role of X-linked and/or various autosomal genes in the etiology of our previously reported familial 46,XY gonadal dysgenesis. 


\section{Subjects and Methods}

\section{Subjects}

The pedigree of the kindred with 46,XY partial gonadal dysgenesis is shown in Fig. 1. Affected subjects include three siblings (III-5, -7, and -9), the proband (IV-8), and her brother (IV-10). Subject IV-10 was born after the initial report of the kindred (23). Subjects II-2 and III-10 are obligate carriers of the trait.

\section{Preparation of genomic DNA}

Peripheral blood leukocytes were obtained from subjects II-2, III-2, III-5 to -11, IV-1 to -8 , and IV-10 and from unrelated normal males and females. Informed consent was obtained in accordance with the investigational review board of the Johns Hopkins University School of Medicine. Genomic DNA was isolated using standard protocols (24).

\section{Southern analysis}

Southern blot analysis was performed as previously described (25). Genomic DNA from all family members was digested with $B g l I I$ and hybridized with the cloned probe USI-59, which reacts with the DXS319 locus (15). This fragment was obtained from Dr. Giovanna Camerino.

\section{Microsatellite polymorphism analysis}

Dinucleotide and trinucleotide repeat polymorphisms from the $X$ chromosome and chromosomes $9 \mathrm{p}, 11 \mathrm{p}$, and $17 \mathrm{q}$ were analyzed as shown in Tables 1 and 2. DNA fragments including the tandem repeat sequences were amplified using PCR in the presence of $\left[\alpha^{-32} \mathrm{P}\right]$ deoxyCTP. The PCR products were separated on $6 \%$ polyacrylamide sequencing gels, which were then exposed to $x$-ray film. In each case, obligate carriers were screened to determine whether they were heterozygous for the specific locus. If heterozygosity was determined, then all family members were tested.
Screening for mutations in the SOX9 gene

The open reading frame of the SOX9 gene was amplified from genomic DNA of patient III-7 and subjected to single strand conformation polymorphism (SSCP) analysis, as described by Kwok et al. (26).

\section{Statistical analysis}

Statistical analysis of the data was performed using the MLINK program from the Linkage package (27). The trait was assumed to be $100 \%$ penetrant, and the gene frequency was assumed to be $0.001 .46, X Y$ individuals were assumed to be fully penetrant for the sex reversal allele, if inherited, whereas 46, XX individuals were not. For analysis of autosomal markers, this required assigning different liability classes based on genotype (28).

\section{Results}

\section{Analysis of loci near DSS}

Analysis of DXS989, DXS319, HMG 122/123, DXS1234, DXS12.38, and DXS1242 showed one allele at each locus for all affected individuals in the kindred (data not shown).

\section{Linkage analysis of X-chromosome loci}

The results of linkage analysis of 29 polymorphic $X$-chromosome loci using the program Linkage are presented in Table 3. Seventeen of these loci had logarithm of the odds (lod) scores less than -2.0 , excluding linkage to the trait. Most of the remaining loci also had negative lod scores, with the exception of DSX7 and MAOA, which were closely linked to each other. Calculation of the lod scores for these loci did not include the genotypes of subjects IV-8 and IV-10, who
II

III

IV

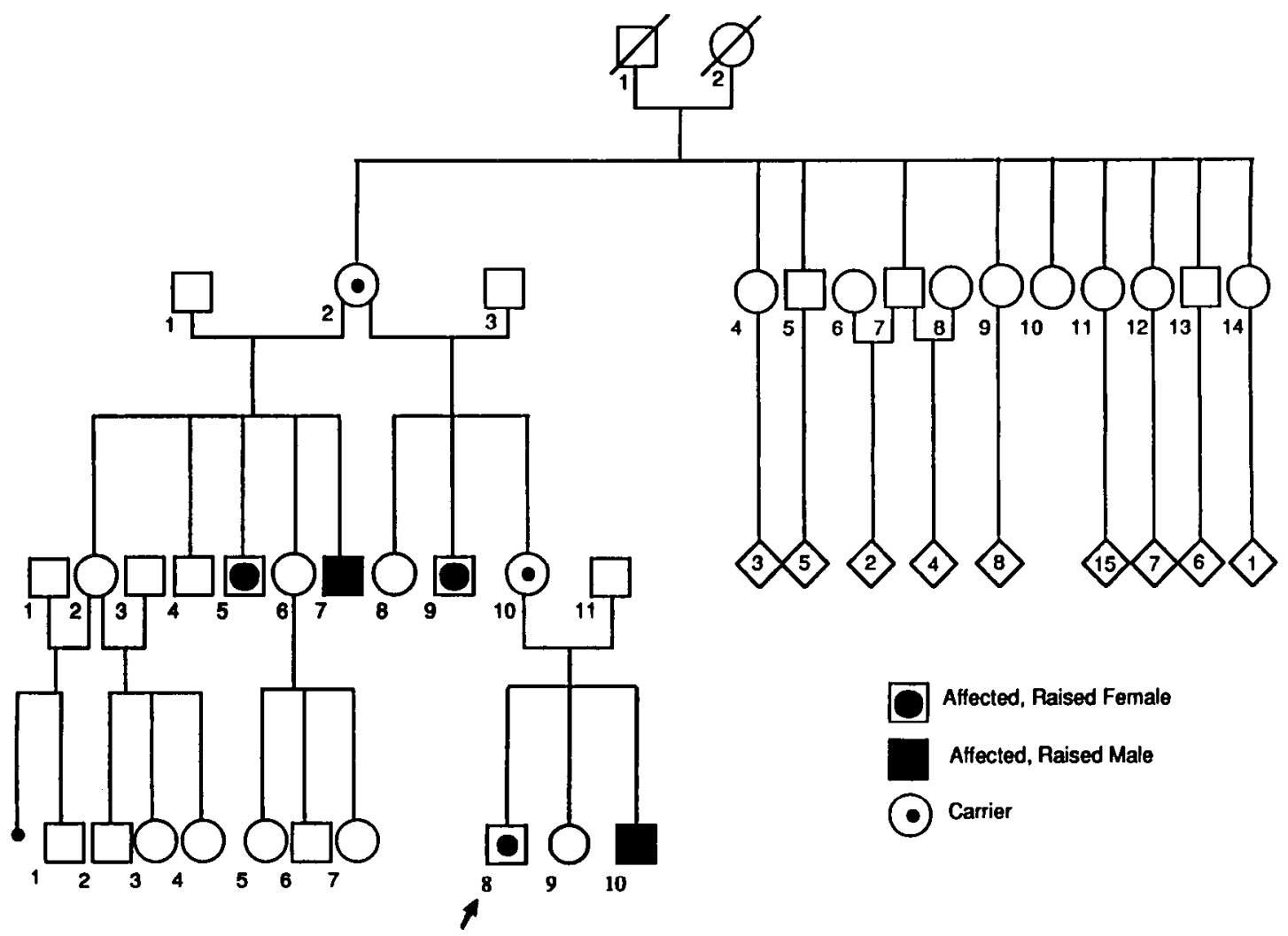

FIG. 1. Pedigree of a kindred with 46,XY partial gonadal dysgenesis. The arrow indicates the proband. 
TABLE 1. X Chromosomal loci

\begin{tabular}{lc}
\hline \multicolumn{1}{c}{ Locus } & Ref. no. \\
\hline DXS996 & 29 \\
KAL & 30 \\
DXS207 & 31 \\
DXS999 & 29 \\
DXS451 & 32 \\
DXS989 & 29 \\
DXS319 & 33 \\
HMG122/123 & Giovana Camerino, personal communication \\
DXS1234 & 34 \\
DXS1238 & 35 \\
DXS1242 & 36 \\
DXS993 & 29 \\
DXS7 & 37 \\
MAOA & 38 \\
MAOA & 39 \\
MAOB & 40 \\
ALAS2 & 41 \\
AR & 42 \\
DXS453 & 29 \\
DXS56 & 43 \\
DXS456 & 44 \\
DXS3 & 45 \\
DXS178 & 46 \\
DXS424 & 44 \\
DXS1114 & 47 \\
DXS294 & 48 \\
DXS297 & 49 \\
FXS1113 & 50 \\
\hline
\end{tabular}

TABLE 2. Autosomal loci

\begin{tabular}{lcc}
\hline Locus & Chromosome & Ref. no. \\
\hline VLDLR & $9 \mathrm{p}$ & 52 \\
D9S143 & $9 \mathrm{p}$ & 53 \\
D9S144 & $9 \mathrm{p}$ & 53 \\
D9S129 & $9 \mathrm{p}$ & 54 \\
WT1 & $11 \mathrm{p}$ & 55 \\
D17S949 & $17 \mathrm{q}$ & 29 \\
\hline
\end{tabular}

were noninformative at these loci. When two closely linked flanking markers, DXS993 and MAOB, were analyzed, lod scores were no longer positive, although they were not sufficiently negative for exclusion.

\section{Linkage analysis of autosomal loci}

Analysis of four polymorphic loci located on distal chromosome $9 p$ excluded linkage between the trait and D9S129 and D9S144. In addition, negative lod scores were calculated for the remaining two loci (Table 4). Analysis of polymorphic loci in the WT1 gene and at D17S949 excluded linkage between these loci and the partial gonadal dysgenesis of this kindred (Table 4).

SSCP analysis of the SOX9 gene of subject III-7 was normal.

\section{Discussion}

In the present study, we considered possible causes of the $46, \mathrm{XY}$ partial gonadal dysgenesis in the family that we previously reported (2.3). In this study, we investigated the possibility of a small duplication of the X-chromosome by searching for heterozygosity of six microsatellite polymor-
TABLE 3. Logarithm of the odds values at three recombination frequencies for $\mathrm{X}$ chromosomal loci

\begin{tabular}{lrrr}
\hline \multirow{2}{*}{ Locus } & \multicolumn{3}{c}{ Recombination frequency } \\
\cline { 2 - 4 } DXS996 & -3.01 & 0.05 & 0.10 \\
KAL & -3.91 & -2.00 & -1.40 \\
DXS207 & -2.51 & -1.91 & -1.12 \\
DXS999 & -2.51 & -1.18 & -0.67 \\
DXS451 & -1.11 & -0.46 & -0.64 \\
DXS989 & -3.40 & -2.00 & -0.23 \\
DXS319 & -2.51 & -1.18 & -1.40 \\
HMG122/123 & -4.21 & -2.19 & -1.67 \\
DXS1234 & -2.51 & -1.18 & -0.67 \\
DXS1238 & -4.21 & -2.18 & -1.37 \\
DXS1242 & -3.40 & -2.00 & -1.40 \\
DXS993 & -1.40 & -0.72 & -0.44 \\
DXS7 & 1.18 & 1.07 & 0.93 \\
MAOA & 1.18 & 1.07 & 0.93 \\
MAOA & 0.08 & 0.65 & 0.79 \\
MAOB & -1.40 & -0.72 & -0.44 \\
ALAS2 & -1.40 & -0.72 & -0.44 \\
AR & -2.22 & -0.93 & -0.46 \\
DXS453 & -0.52 & -0.09 & 0.28 \\
DXS56 & -1.92 & -0.63 & -0.17 \\
DXS456 & -0.53 & 0.05 & 0.20 \\
DXS3 & -2.51 & -1.18 & -0.67 \\
DXS178 & -3.40 & -2.00 & -1.40 \\
DXS424 & -3.91 & -1.91 & -1.12 \\
DXS1114 & -1.40 & -0.72 & -0.44 \\
DXS294 & -1.40 & -0.72 & -0.44 \\
DXS297 & -0.52 & -0.09 & 0.28 \\
DXS1113 & -3.91 & -1.91 & -1.12 \\
F8 & -4.22 & -2.21 & -1.41 \\
\hline & & & \\
\hline
\end{tabular}

phisms near the DSS locus. The polymorphism defined by the HMG 122/123 locus is, in fact, located within the DSS locus (Camerino, G., personal communication). Two other loci (DXS989 and DXS319) are located within a region approximately 5 centimorgans telomeric to DSS, and the three additional loci are located within a region 12 centimorgans in length on the centromeric side of the DSS locus (56). We were unable to find evidence of microduplication in the DSS locus, but our studies do not completely exclude it.

We subsequently investigated the possibility that the abnormality in the family that we studied was related to another X-linked gene. We performed an extensive analysis of 29 polymorphic loci distributed along the X-chromosome at 5- to 15-centimorgan intervals. These loci were selected because of their high rates of heterozygosity in the general population. Considering the number of informative meioses within the pedigree, we could expect a maximum lod score of 2.7, which in itself would have been sufficient to establish linkage for an X-linked trait. However, the lod scores obtained suggest that an $\mathrm{X}$-chromosome gene was not responsible.

Several problems may have influenced our study. First, it is possible that a new mutation in an allele at a given $X$ chromosome locus may have produced an alteration in the number of tandem repeat units, thereby obscuring linkage between that locus and the trait. However, such an event is considered to be rare (57). Second, as the number of family members presented here is relatively small, the statistical power of our study is somewhat limited. A single recombination event between a weakly linked locus and the trait 
TABLE 4. Logorithm of the odds values at three recombination frequencies for autosomal loci

\begin{tabular}{llcc}
\hline \multirow{2}{*}{ Locus } & \multicolumn{3}{c}{ Recombination frequency } \\
\cline { 2 - 4 } & 0.01 & 0.05 & 0.10 \\
\hline VLDLR & -1.40 & -0.72 & -0.44 \\
D9S129 & -4.21 & -2.16 & -1.33 \\
D9S143 & -1.78 & -1.01 & -0.65 \\
D9S144 & -2.22 & -0.91 & -0.42 \\
WT1 & -2.97 & -1.58 & -0.99 \\
D17S949 & -2.58 & -1.24 & -0.72 \\
\hline
\end{tabular}

would result in a reduction of the lod score from a maximum of 2.7 to a value that would be statistically insignificant. We tried to minimize this possibility by studying loci that were separated by narrow intervals. This problem could be minimized in the future by the combination of this family and several similar families. As no other kindreds with $46, X Y$ partial gonadal dysgenesis have been reported, this is not currently possible.

In subsequent studies, we investigated the role of the WT1 gene, the putative sex-determining gene on chromosome 9 , and the SOX9 gene. With respect to WT1, we examined a microsatellite polymorphism within the $3^{\prime}$-untranslated region of the WT1 gene (55) and demonstrated that this gene was not linked to $46, \mathrm{XY}$ partial gonadal dysgenesis in the family under study. We examined four loci located on the short arm of chromosome 9 from the terminal region of $9 p$ to 9 p23. Our data excluded linkage between two of these loci and the trait and suggested that the other two loci were also unlinked. We also studied a polymorphic locus in the same region as the SOX9 gene on chromosome $17 \mathrm{q}$ and screened the open reading frame of the SOX9 gene using SSCP analysis. These data suggested that an abnormality of the SOX9 gene was not responsible for the trait in the kindred we studied.

Our studies strongly suggest that the gene responsible for the abnormality in the family we studied is not on the $X$ chromosome, but they do not formally exclude it. They imply a role of an autosomal gene, but suggest that the affected gene is not WT1, the putative gene on the short arm of chromosome 9, or the SOX9 gene.

\section{Acknowledgments}

The authors thank Margaret MacGillivray, M.D., for assistance in obtaining patient material, Namrata Patel and John McLaughlin for technical assistance, Deborah Meyers and Eugene Taylor for statistical analysis, and Kathy Whitehurst for secretarial assistance.

\section{References}

1. Berkovitz GD, Fechner PY, Zacur HW, et al. 1991 Clinical and pathologic spectrum of $46, X Y$ gonadal dysgenesis: its relevance to the understanding of sex differentiation. Medicine. 70:375-383.

2. Sinclair AH, Berta P, Palmer JS, et al. 1990 A gene from the human sex determining region encodes a protein with homology to a conserved DNA binding motif. Nature. 346:240-244.

3. Affara NA, Chalmers EJ, Ferguson-Smith MA. 1993 Analysis of the SRY gene in 22 sex reversed $X Y$ females identifies four new point mutations in the conserved DNA binding domain. Hum Mol Genet. 2:785-789.

4. Hawkins JR. 1993 Mutational analysis of SRY in XY females. Hum Mutat. 2:347-350.

5. McElreavey K, Villain E, Abbas N, et al. 1992 XY sex reversal associated with a deletion 5 ' to the SRY "HMG-box" in the testis determining region. Proc Natl Acad Sci USA. 89:11016-11020.
6. Sternberg WH, Barclay DL, Kloepfeer HW. 1968 Familial XY gonadal dysgenesis. N Engl J Med. 278:695-700.

7. Espiner EA, Veale MO, Sands VE, Fitzgerald PH. 1970 Familial syndrome of streak gonads and normal male karyotype in five phenotypic females. $\mathrm{N}$ Engl J Med. 283:6-11.

8. German J, Simpson JL, Summitt RL, Reid LB, Merkatz IR. 1978 Genetically determined sex-reversal in 46,XY humans. Science. 202:52-56.

9. Mann JR, Corkery JJ, Fisher HJW, et al. 1983 The X-linked recessive form of $X Y$ gonadal dysgenesis with a high incidence of gonadal germ cell tumors: clinical and genetic studies. J Med Genet. 20:264-270.

10. Scherer G, Schempp W, Baccichetti C, Lenzini E, Bricarelli FD, Carbone LDL. 1989 Duplication of an $\mathrm{Xp}$ segment that includes the ZFX locus causes sex inversion in man. Hum Genet. 81:291-294.

11. Stern HJ, Garrity AM, Saal HM, Wangsa D, Disteche CM. 1990 Duplication $\mathrm{Xp} 21$ and sex reversal: insight into the mechanism of sex determination. Am J Hum Genet. 47(Suppl):A41.

12. May KM, Grinzaid KA, Blackston RD. 1991 Sex reversal and multiple abnormalities due to abnormal segregation of $t(X: 16)(p 11.4 ; p 13.3)$. Am J Hum Genet. 49(Suppl):19A.

13. Ogata T, Hawkins JR, Taylor A, Matsuo N, Hala J, Goodfellow PN. 1992 Sex reversal in a child with a $46, X Y \mathrm{p}+$ karyotype: support for the existence of a gene, located in distal $\mathrm{Xp}$, involved in testis formation. J Med Genet. 29:226 230

14. Bernstein R, Jenkins T, Dawson B, et al. 1980 Female phenotype and multiple abnormalities in sibs with a $X$ chromosome and partial $X$ chromosome duplication: $\mathrm{H}-\mathrm{Y}$ antigen and $\mathrm{Xg}$ blood group findings. J Med Genet. 17:291-300.

15. Bardoni B, Zanaria E, Guioli S, et al. 1994 A dosage sensitive locus at chromosome Xp21 is involved in male to female sex reversal. Nat Genet. 7:497-501.

16. Gibbons RJ, Brueton L, Buckle VJ, et al. 1995 Clinical and hematologic aspects of the X-linked $\alpha$-thalassemia/mental retardation syndrome (ATR-X). Am J Med Genet. 55:288-299.

17. Gibbons RJ, Picketts DJ, Villard L, Higgs DR. 1995 Mutation in a putative global transcriptional regulator cause X-linked mental retardation with $\alpha$-thalassemia (ATR- $X$ syndrome). Cell. 80:837-845.

18. Pelletier J, Bruening W, Kastan CE, et al. 1991 Germline mutations in the Wilms' tumor suppressor gene are associated with abnormal urogenital development in Denys-Drash syndrome. Cell. 67:437-447.

19. Foster JW, Dominguez-Steglich MA, Guioli S, et al. 1994 Camptomelic dysplasia and autosomal sex reversal caused by mutations in an SRY-related gene. Nature. 372:525-530.

20. Houston CS, Opitz JM, Spranger JW, et al. 1983 The campomelic syndrome: Review, report of 17 cases and follow-up on the currently 17-year old boy first reported by Maroteaux et al in 1971. Am J Med Genet. 15:3-28.

21. Jotterand M, Juillard E. 1976 A new case of trisomy for the distal part of $13 q$ due to maternal translocation, $t(9 ; 13)(p 21 \leqslant 1)$. I Ium Genet. 33;213-222.

22. Crocker M, Coghill SB, Cortinho R. 1988 An unbalanced autosomal translocation $(7 ; 9)$ associated with feminization. Clin Genet. 34:70-73.

23. Fechner PY, Marcantonio SM, Ogata T, et al. 1993 Report of a kindred with X-linked (or autosomal dominant sex-limited) 46,XY partial gonadal dysgenesis. J Clin Endocrinol Metab. 76:1248-1253.

24. Sambrook J, Fritsch EF, Maniatis T. 1989 Molecular Cloning-A Laboratory Manual, 2nd ed. Cold Spring Harbor: Cold Spring Harbor Laboratory; 9.16-9.19.

25. Fechner PY, Smith KD, Jabs EW, Migeon CJ, Berkovitz GD. 1992 Partial gonadal dysgenesis in a patient with a marker $Y$ chromosome. Am J Med Genet. 42:808-812.

26. Kwok C, Weller PA, Guioli S, et al. 1995 Mutations in SOX9, the gene responsible for camptomelic dysplasia and autosomal sex reversal. Am J Hum Genet. 57:1028-1036.

27. Lathrop GM, Lalouel JM, Julier C, Ott J. 1984 Strategies for multilocus linkage analysis in humans. Proc Natl Acad Sci USA. 81:3443-3446.

28. Terwilliger JD, Ott J. 1994 Handbook of human genetic linkage. Baltimore: Johns Hopkins University Press.

29. Gyapay G, Morissette J, Vignal A, et al. 1994 The 1993-94 Genethon human genetic linkage map. Nat Genet. 7:246-339.

30. Bouloux P-MG, Hardelin J-P, Munroe P, et al. 1991 A dinucleotide repeat polymorphism at the Kallmann locus (Xp22.3). Nucleic Acids Res. 19:5453.

31. Oudet C, Weber C, Kaplan J, et al. 1992 Characterization of a highly polymorphic microsatellite at the DXS207 locus: confirmation of very close linkage to the retinoschesis disease gene. J Med Genet. 30:300-303.

32. Browne D, Barker D, Litt M. 1992 Dinucleotide repeat polymorphism at the DXS365, DXS443 and DXS451 loci. Hum Mol Genet. 1:213.

33. Barker DF, Dietz-Band JN, Donaldson CW, et al. 1989 Further isolation, characterization and physical location of $X$ chromosome RFLP markers, comparing VNTR-directed and random isolation strategies. Cytogenet Cell Genet. $51: 958$.

34. Beggs A, Kunkel L. 1990 A polymorphic CACA repeat in the 3' untranslated region of dystrophin. Nucleic Acids Res. 18:1931.

35. Clemens PR, Fenwich RG, Chamberlain IS, et al. 1991 Carrier detection and prenatal diagnosis in Duchenne and Becker muscular dystrophy families, using dinucleotide repeat polymorphisms. Am J Hum Gen. 49:951-960.

36. Feener CA, Boyce FM, Kunkel LM. 1991 Rapid detection of CA polymor- 
phisms in cloned DNA: application to the $5^{\prime}$ region of the dystrophin gene. Am J Hum Genet. 48:621-627.

37. Moore BJ, Kwan S-P, Bech-Hansen NT. 1992 A polymorphic dinucleotide repeat at the DXS7 locus. Nucleic Acids Res. 20:929.

38. Hinds H, Hendricks RW, Craig IW, Chen Z-Y. 1992 Characterization of a highly polymorphic region near the first exon of the human MAOA gene containing a GT dinucleotide and a novel VNTR motif. Genomics. 13:896-897.

39. Black GCM, Chen Z-Y, Craig IW, Powell JF, 1991 Dinucleotide repeat polymorphism at the MAOA locus. Nucleic Acids Res. 19:689.

40. Grimsby J, Chen K, Devor EJ, Cloniger CR, Shih JC. 1992 Dinucleotide repeat $(\mathrm{TG})_{23}$ polymorphism in the MAOB gene. Nucleic Acids Res. 20:924.

41. Cox TC, Kozman HM, Raskind WH, May BK, Mulley JC. 1992 Identification of a highly polymorphic marker within intron 7 of the ALAS2 gene and suggestion of at least two loci for X-linked sideroblastic anemia. Hum Mol Genet. 1:639-641.

42. Edwards A, Hammond HA, Jin L, Caskey CT, Chakraborty R. 1992 Genetic variation of five trimeric and tetrameric tandem repeat loci in four human population groups. Genomics. 12:241-253.

43. Graeber MB, Monaco AP, Chelly J, Müller U. 1992 Isolation of DNTR polymorphisms from yeast artificial chromosomes encompassing $X$ chromosomal loci PGK1 and DSX56. Hum Genet. 90:270-274.

44. Luty JA, Guo Z, Willard HF, Ledbetter DH, Ledbetter S, Litt M. 1990 Five polymorphic microsatellite VNTRs on the human $X$ chromosome. Am J Hum Genet. 46:776-783.

45. Stainier P, Newton R, Forbes SA, Ivens A, Moore GE. 1991 Polymorphic dinucelotide repeat at the DXS3 locus. Nucleic Acids Res. 19:4793.

46. Allen RC, Belmont JW. 1992 Dinucleotide repeat polymorphism at the DXS 178 locus. Hum Mol Genet. 1:216.

47. Weber C, Oudet C, Johnson S, Pilla G, Schlessinger D, Hanauer A. 1993a
Dinucleotide repeat polymorphism at Xq26.1 (DXS1114). Hum Mol Genet. 2:612.

48. Gedeon AK, Richards RI, Mulley JC. 1991 Dinucleotide repeat polymorphisms at the DXS294 and DSX300 loci in Xq26. Nucleic Acids Res. 19:5087.

49. Richards RI, Shen Y, Holman K, et al. 1991 Fragile X syndrome: diagnosis using highly polymorphic microsatellite markers. Am J Hum Genet. 48:1051-1057.

50. Weber C, Oudet C, Johnson S, Pilla G, Schlessinger D, Hanauer A. 1993b Dinucleotide repeat polymorphism close to IDS gene in Xq27.3-q28 (DSX1113). Hum Mol Genet. 2:612.

51. Lalloz MR, McVey JH, Pattinson JK, Tuddenham EGD. 1991 Haemophilia A diagnosis by analysis of a hypervariable dinucleotide repeat within the factor VIII gene. Lancet. 338:207-211.

52. Sakai J, Hoshino A, Takahashi S, et al. 1994 Structure, chromosome location and expression of the human very low density lipoprotein receptor gene. J Biol Chem. 269:2173-2182.

53. Furlong RA, Lyall JEW, Lush MJ, Affara NA, Ferguson-Smith MA. 1992 Four dinucleotide repeat polymorphisms on chromosome 9 (D9S143-146). Hum Mol Genet. 1:447.

54. Hudson TJ, Engelstein M, Lee MK, et al. 1992 Isolation and chromosomal assignment of 100 highly informative simple sequence repeat polymorphisms. Genomics. 13:662-629.

55. Gessler M, Konig A, Bruns GAP. 1992 The genomic organization and expression of the WT1 gene. Genomic. 12:807-813.

56. Wang LH, Collins A, Lawrence S, Keats BJ, Morton E. 1994 Integration of gene maps; chromosome X. Genomics. 22:590-604.

57. Tautz D. 1989 Hypervariability of simple sequences as a general source for polymorphic DNA markers. Nucleic Acids Res. 17:6463-6471. 